IZA DP No. 7894

The Individual and Joint Performance of Economic Preferences, Personality, and Self-Control in Predicting Criminal Behavior

Tim Friehe

Hannah Schildberg-Hörisch

January 2014 


\title{
The Individual and Joint Performance of Economic Preferences, Personality, and Self-Control in Predicting Criminal Behavior
}

\author{
Tim Friehe \\ CASTLE, University of Bonn \\ and CESifo \\ Hannah Schildberg-Hörisch \\ University of Bonn \\ and IZA
}

Discussion Paper No. 7894

January 2014

IZA

P.O. Box 7240

53072 Bonn

Germany

Phone: +49-228-3894-0

Fax: +49-228-3894-180

E-mail: iza@iza.org

\begin{abstract}
Any opinions expressed here are those of the author(s) and not those of IZA. Research published in this series may include views on policy, but the institute itself takes no institutional policy positions. The IZA research network is committed to the IZA Guiding Principles of Research Integrity.

The Institute for the Study of Labor (IZA) in Bonn is a local and virtual international research center and a place of communication between science, politics and business. IZA is an independent nonprofit organization supported by Deutsche Post Foundation. The center is associated with the University of Bonn and offers a stimulating research environment through its international network, workshops and conferences, data service, project support, research visits and doctoral program. IZA engages in (i) original and internationally competitive research in all fields of labor economics, (ii) development of policy concepts, and (iii) dissemination of research results and concepts to the interested public.
\end{abstract}

IZA Discussion Papers often represent preliminary work and are circulated to encourage discussion. Citation of such a paper should account for its provisional character. A revised version may be available directly from the author. 


\section{ABSTRACT}

\section{The Individual and Joint Performance of Economic Preferences, Personality, and Self-Control in Predicting Criminal Behavior}

We explore the individual and joint explanatory power of concepts from economics, psychology, and criminology for criminal behavior. More precisely, we consider risk and time preferences, personality traits from psychology (Big Five and locus of control), and a selfcontrol scale from criminology. We find that economic preferences, personality traits, and self-control complement each other in predicting criminal behavior. The most significant predictors stem from all three disciplines: risk aversion, conscientiousness, and high selfcontrol make criminal behavior less likely. Our results illustrate that integrating concepts from various disciplines enhances our understanding of individual behavior.

JEL Classification: K42, D03, D81, D90, C21, C91

Keywords: crime, risk preferences, time preferences, personality traits, self-control, experiment

Corresponding author:

Hannah Schildberg-Hörisch

Department of Economics

University of Bonn

Adenauerallee 24-42

53113 Bonn

Germany

E-mail: schildberg-hoerisch@uni-bonn.de 


\section{Introduction}

Crime is a social phenomenon with tremendous monetary and psychic costs (Anderson, 1999). Numerous disciplines study the causes of criminal behavior. To explain heterogeneity in criminal behavior, we combine concepts from economics, psychology, and criminology that refer to differences in stable individual characteristics. We investigate the individual and joint explanatory power of risk and time preferences, personality traits from psychology (Big Five and locus of control) and a self-control scale developed by criminologists (Grasmick, 1993), using data from a laboratory experiment and a questionnaire.

Our paper makes two contributions: We are the first to combine economic preferences and personality traits to predict criminal behavior. We find that, when used individually, both economic preferences and personality traits have explanatory power for criminal behavior. Furthermore, they complement each other, i.e., their joint explanatory power exceeds their individual explanatory power (even when correcting for the higher number of explanatory variables). This result adds to the emerging field that integrates personality traits and economic preferences (Almlund et al., 2011, Becker et al., 2012, Borghans et al., 2008).

Second, we compare the explanatory power of the very general concepts of economic preferences and personality traits to that of a self-control scale specifically tailored to predict criminal behavior. Our results imply that the specialized self-control measure does not outperform the explanatory power of preferences and personality traits. Moreover, preferences, personality traits, and self-control are complements in explaining criminal behavior.

In economics, preferences are central determinants of individual behavior. Seminal theoretical contributions (Becker, 1968, Davis, 1988) explore the link between risk and time preferences and the individual propensity to engage in crime.

In psychology, the Big Five (openness, conscientiousness, extraversion, agreeableness, and neuroticism) and locus of control ${ }^{1}$ are broad domains used to describe personality and assumed to be decisive for individual behavior (Costa and McCrae, 1992, Rotter, 1966). Heaven (1996) was the first to study the relationship between the Big Five and delinquency. In criminology, the influential General Theory of Crime argues that low self-control is the primary individual characteristic causing criminal behavior and describes people with low

\footnotetext{
${ }^{1}$ Locus of control assesses how much people believe that they have control over their life outcomes.
} 
self-control as impulsive, insensitive, physical (as opposed to mental), risk-taking, shortsighted, and non-verbal (Gottfredson \& Hirschi, 1990). Based on this definition, Grasmick et al. (1993) construct a widely used self-control scale, capturing not only aspects of economic preferences and Big Five but also many further components. Pratt and Cullen (2000) and Engel (2012)'s meta-analyses confirm that self-control is indeed a significant predictor of criminal behavior. Like personality traits and preferences, self-control is considered to be stable over time (e.g., Cobb-Clark and Schurer, 2012).

\section{Data}

We conducted an experiment (using z-Tree, Fischbacher, 2007) at the BonnEconLab, Germany. Student subjects were recruited randomly from all majors (using ORSEE, Greiner, 2003). We use two complementary measures for an individual's inclination to engage in criminal behavior. Both belong to the domain of "small crime" typically only enforced by non-deterrent legal sanctions (Tyran and Feld, 2006). First, in an incentivized "stealing game", participants decided how many points to steal from another anonymous, passive participant. Both participants were endowed with 20 points (each point was later exchanged in 0.25 Euro). For each point stolen, the stealing participant earned only 0.25 points (efficiency loss). There was no probabilistic sanctioning scheme. ${ }^{2}$ The second measure for the attitude towards crime consists of responses to the post-experimental questionnaire. We asked participants how they would react if they learned that a close acquaintance had taken one of the following actions: drunk driving, fare dodging, or evading taxes (Traxler and Winter, 2012). For each action, participants were asked to select one of five response categories: approval, benevolently ignoring it (two categories), sanctions in the form of expressing disapproval, and social exclusion. Responses are coded such that a higher number represents stronger disapproval. Taken literally, the answers are judgments of other's law violations. We assume that they additionally reflect a participant's own propensity to engage in the respective "small crimes". ${ }^{3}$ The indirect approach makes misreporting less likely.

\footnotetext{
${ }^{2}$ For a more detailed description of the experiment see Friehe and Schildberg-Hörisch (2013).

${ }^{3}$ Engels et al. (2004) and Henle et al. (2010) discuss the close association of attitudes towards and propensity to rule-breaking conduct.
} 
Our explanatory variables encompass questionnaire measures of age, gender, risk and time preferences, personality traits, and the self-control scale. The risk preference question is taken from the German Socioeconomic Panel (SOEP) survey: "How do you see yourself: Are you generally a person who is fully prepared to take risks, or do you try to avoid risks?" using a scale from 0 ("unwilling...") to 10 ("fully prepared to take risks"). The time preference questions reads: "How would you assess your willingness to give up something today in order to benefit from that in the future when it comes to financial decisions?" with a scale from 0 to 3, where higher values indicate higher levels of patience (Falk et al., 2013). To obtain measures of the Big Five, we use the inventory of Rammstedt and John (2007). Locus of control is elicited using 10 items that have been adapted from Rotter (1966) and used in the SOEP in 2005. In order to aggregate items into a single measure of locus of control or a facet of Big Five, we standardize items, sum them up, and standardize the overall measure. For each personality trait, a higher value represents a stronger intensity of that trait (e.g., being more conscientious). Finally, we measure self-control as proposed by Grasmick et al. (1993) who construct a 24 item-scale. A high score indicates low self-control.

\section{Empirical Strategy}

For each of the four dependent variables, we display five specifications. In specifications (1) and (2), we include either economic preferences or personality traits as explanatory variables. In specification (3), we use both preferences and personality traits. Specification (4) uses self-control as explanatory variable. Finally, in specification (5), we combine the concepts from economics, psychology, and criminology to predict criminal behavior. We always use age and gender as control variables since male and younger individuals are more likely to commit crimes (e.g., Hirschi and Gottfredson, 1983, Steffensmeier and Allan, 1996). ${ }^{4}$ The dummy variable male is equal to one for male subjects.

We seek to compare the individual explanatory power of preferences, personality traits, and self-control, and to assess whether they complement or substitute each other in explaining criminal behavior. As a criterion for comparing the explanatory power of different specifications, we use adjusted $\mathrm{R}^{2}$ for OLS regressions (stealing) and McFadden's Adjusted Pseudo $\mathrm{R}^{2}$ for ordered logit regressions (drunk driving, fare dodging, tax evasion). In contrast

\footnotetext{
${ }^{4}$ In our data, age ranges from 18 to $33.43 \%$ of the participants are male.
} 
to Adjusted $\mathrm{R}^{2}$ in OLS regressions, McFadden's Adjusted Pseudo $\mathrm{R}^{2}$ can take negative values. A higher Adjusted (Pseudo) $R^{2}$ indicates that a model has higher predictive power.

\section{Results}

Tables 1-3 contain results for drunk driving, fare dodging, and evading taxes, Table 4 for the incentivized stealing decision.

\section{INSERT TABLES 1-4 HERE}

With regard to economic preferences, specification (1) in Tables 1-4 conveys that risk preferences are a significant predictor of criminal behavior, while patience is not. ${ }^{5}$ Less riskaverse individuals judge drunk driving and fare dodging as less severe violations of the law. Risk preferences are not a significant predictor for tax evasion or stealing. The insignificance for stealing is plausible since the stealing decision did not involve a probabilistic punishment. ${ }^{6}$ Specification (2) in Tables 1-4 shows that personality traits have explanatory power for all four dependent variables, and that intuitive effects emerge. More conscientious individuals consider drunk driving, fare dodging, and tax evasion as more serious, while more neurotic individuals do so for drunk driving and fare dodging. More agreeable individuals judge tax evasion to be more severe. Individuals who score higher on extraversion steal higher amounts. The results on conscientiousness, agreeableness, and extraversion are in line with Almlund et al. (2011). Comparing the explanatory power of economic preferences to that of personality traits as measured by Adjusted (Pseudo) $R^{2}$, personality traits perform slightly better in three of four cases.

Result 1: Both economic preferences and personality traits have explanatory power for criminal behavior.

Column (3) in Tables 1-4 reveals that preferences and personality traits are complements in predicting criminal behavior. Risk preferences and conscientiousness are the most significant predictors. For three out of four dependent variables, Adjusted (Pseudo) $R^{2}$ are higher than in columns (1) and (2).

\footnotetext{
${ }^{5}$ Nagin and Pogarsky (2004) provide evidence that high discounting predicts property offending, but not violent crime.

${ }^{6}$ Schildberg-Hörisch and Strassmair (2012) and Harbaugh et al. (2013) show that risk preferences significantly affect stealing in a laboratory experiment with a probabilistic sanctioning scheme.
} 
Result 2: Economic preferences and personality traits are complements in predicting criminal behavior.

Column (4) in Tables 1-4 documents that self-control is a significant predictor of criminal behavior (as argued by Gottfredson and Hirschi, 1990 and confirmed by Pratt and Cullen, 2000, Engel, 2012). Individuals with lower self-control consider fare dodging and tax evasion as less severe and steal higher amounts. In contrast to economic preferences and personality traits - both very general concepts that aim at explaining all kinds of individual behavior - the self-control scale was especially designed to explain delinquency. Having this in mind, it is remarkable that the explanatory power of self-control does not outperform the one of preferences or personality traits: the Adjusted (Pseudo) $R^{2}$ in column (4) is never highest when compared to columns (1) and (2).

Result 3: Self-control has explanatory power for criminal behavior.

Columns (5) in Tables 1-4 reveal that preferences and personality traits remain important predictors even when using self-control as explanatory variable. For three out of four dependent variables, Adjusted (Pseudo) $R^{2}$ is highest in specification (5). Both findings indicate that preferences, personality traits, and self-control are complements in predicting criminal behavior.

Result 4: Economic preferences, personality traits, and self-control are complements in predicting criminal behavior.

\section{Conclusions}

Our results document that economic preferences, personality traits, and the self-control scale developed by criminologists complement each other in predicting criminal behavior. The most significant predictors of criminal behavior, namely risk aversion, conscientiousness, and self-control, stem from all three disciplines. Taking a broader perspective, our results illustrate that integrating concepts from various disciplines enhances our understanding of individual behavior and, thus, is a promising avenue for future research. 


\section{Acknowledgements}

Financial support from SFB-TR 15 and helpful comments from Fabian Kosse are gratefully acknowledged.

\section{References}

Almlund, M., Duckworth, A., Heckman, J., Kautz, T., 2011. Personality psychology and economics, in: Hanushek, E. A., Machin, S., Woessmann, L. (Eds.), Handbook of the economics of education. North Holland, San Diego, 1-181.

Anderson, D.A., 1999. The aggregate burden of crime. Journal of Law and Economics 42, 611-642.

Becker, A., Deckers, T., Dohmen, T., Kosse, F., Falk, A., 2012. The relationship between economic preferences and psychological personality measures. Annual Review of Economics 4, 453-478.

Becker, G.S., 1968. Crime and punishment: an economic approach. Journal of Political Economy 76, 169-217.

Borghans, L., Duckworth, A.L., Heckman, J.J., ter Weel, B., 2008. The economics and psychology of personality traits. Journal of Human Resources 43, 972-1059.

Cobb-Clark, D.A., Schurer, S., 2012. The stability of big-five personality traits. Economics Letters $115,11-15$.

Costa, P.T., Jr., McCrae, R.R., 1992. Revised NEO personality inventory (NEO-PI-R) and NEO five-factor inventory (NEO-FFI) manual. Odessa, FL: Psychological Assessment Resources.

Davis, M.L., 1988. Time and punishment: an intertemporal model of crime. Journal of Political Economy 96, 383-390.

Engel, C., 2012. Low self-control as a source of crime, a meta-study. Preprint of the Max Planck Institute for Research on Collective Goods Bonn 2012/4.

Engels, R., Luijpers, E., Landsheer, J., Meeus, W., 2004. A longitudinal study of relations between attitudes and criminal behavior in adolescents. Criminal Justice and Behavior 31, 244-260.

Falk, A., Becker, A., Dohmen, T., Huffman, D., Sunde, U., 2013. An experimental validated preference survey module. mimeo.

Fischbacher, U., 2007. z-Tree: Zurich toolbox for ready-made economic experiments. Experimental Economics 10, 171-178. 
Friehe, T., Schildberg-Hörisch, H., 2013. Crime and self-control revisited: disentangling the effects of self-control on risk and social preferences. Mimeo.

Grasmick, H.G., Tittle, C.R., Bursik, R.J., Arneklev, B.J., 1993. Testing the core empirical implications of Gottfredson and Hirschi's General Theory of Crime. Journal of Research in Crime and Delinquency 30, 5-29.

Greiner, B., 2003. An online recruitment system for economic experiments, in: Kremer, K., and Macho, V. (Eds.), Forschung und wissenschaftliches Rechnen. GWDG Bericht 63, Göttingen: Ges. für Wiss. Datenverarbeitung, 79-93.

Harbaugh, W.T., Mocan, N., Visser, M.S., 2013. Theft and deterrence. Journal of Labor Research 34, 389-407.

Heaven, P.C.L., 1996. Personality and self-reported delinquency: analysis of the "Big Five" personality dimensions. Personality and Individual Differences 20, 47-54.

Henle, C.A., Reeve, C.L., Pitts, V.E., 2010. Stealing time at work: attitudes, social pressure, and perceived control as predictors of time theft. Journal of Business Ethics 94, 53-67.

Hirschi, T. and Gottfredson, M.R., 1983. Age and the explanation of crime. American Journal of Sociology 89, 552-584.

Gottfredson, M.R., Hirschi, T., 1990. A general theory of crime. Stanford University Press, Stanford, CA.

Nagin, D.S., Pogarsky, G., 2004. Time and punishment: delayed consequences and criminal behavior. Journal of Quantitive Criminology 20, 295-317.

Pratt, T.C., Cullen, F.T., 2000. The empirical status of Gottfredson and Hirschi's General Theory of Crime: a meta-analysis. Criminology 38, 931-964.

Rammstedt, B., John, O.P., 2007. Measuring personality in one minute or less: a 10-item short version of the Big Five inventory in English and German. Journal of Research in Personality 41, 203-212.

Rotter, J., 1966. Generalized expectancies for internal versus external control of reinforcement. Psychological Monographs 80, 1-28.

Schildberg-Hörisch, H., Strassmair, C., 2012. An experimental test of the deterrence hypothesis. Journal of Law, Economics, and Organization 28, 447-459.

Steffensmeier, D., Allan, E., 1996. Gender and crime, toward a gendered theory of female offending. Annual Review of Sociology 22, 459-487. 
Traxler, C., Winter, J., 2012. Survey evidence on conditional norm enforcement. European Journal of Political Economy 28, 390-398.

Tyran, J.-R., Feld, L., 2006. Achieving compliance when legal sanctions are non-deterrent. Scandinavian Journal of Economics 108, 135-156.

\section{Appendix: Tables}

Table 1: The relationship between fare dodging and economic preferences, personality traits, self-control (ordered logit estimates)

\begin{tabular}{|c|c|c|c|c|c|}
\hline Explanatory variables & $(1)$ & $(2)$ & (3) & (4) & $(5)$ \\
\hline \multirow[t]{2}{*}{ Age } & -0.168 & -0.585 & -0.424 & -0.496 & -0.563 \\
\hline & [0.549] & {$[0.636]$} & {$[0.581]$} & {$[0.590]$} & {$[0.646]$} \\
\hline \multirow[t]{2}{*}{$\mathrm{Age}^{2}$} & 0.006 & 0.014 & 0.011 & 0.013 & 0.014 \\
\hline & [0.011] & [0.013] & {$[0.012]$} & {$[0.012]$} & [0.013] \\
\hline \multirow[t]{2}{*}{ Male } & -0.47 & -0.431 & -0.183 & -0.593 & -0.182 \\
\hline & [0.389] & {$[0.420]$} & [0.442] & [0.384] & [0.448] \\
\hline \multirow[t]{2}{*}{ Risk preferences } & $-0.364 * * *$ & & $-0.320 * * *$ & & $-0.201^{*}$ \\
\hline & {$[0.090]$} & & [0.094] & & [0.107] \\
\hline \multirow[t]{2}{*}{ Time preferences } & 0.288 & & 0.146 & & 0.049 \\
\hline & [0.272] & & {$[0.287]$} & & {$[0.296]$} \\
\hline \multirow[t]{2}{*}{ Extraversion } & & -0.24 & -0.088 & & -0.045 \\
\hline & & [0.207] & {$[0.215]$} & & [0.232] \\
\hline \multirow[t]{2}{*}{ Agreeableness } & & -0.084 & -0.104 & & -0.181 \\
\hline & & {$[0.165]$} & {$[0.186]$} & & [0.197] \\
\hline \multirow[t]{2}{*}{ Conscientiousness } & & $0.527^{* * *}$ & $0.425 * *$ & & 0.243 \\
\hline & & [0.175] & [0.179] & & [0.194] \\
\hline \multirow[t]{2}{*}{ Neuroticism } & & $0.394 * *$ & 0.275 & & $0.406^{*}$ \\
\hline & & {$[0.196]$} & {$[0.202]$} & & {$[0.220]$} \\
\hline \multirow[t]{2}{*}{ Openess } & & -0.066 & 0.078 & & 0.068 \\
\hline & & [0.172] & {$[0.178]$} & & {$[0.172]$} \\
\hline \multirow[t]{2}{*}{ Locus of control } & & 0.174 & 0.076 & & -0.100 \\
\hline & & [0.220] & {$[0.235]$} & & [0.253] \\
\hline \multirow[t]{2}{*}{ Self-control } & & & & $-0.081 * * *$ & $-0.074 * * *$ \\
\hline & & & & [0.020] & [0.028] \\
\hline $\mathrm{N}$ & 180 & 180 & 180 & 180 & 180 \\
\hline Pseudo $\mathrm{R}^{2}$ & 0.104 & 0.086 & 0.132 & 0.095 & 0.160 \\
\hline Adjusted Pseudo $\mathrm{R}^{2}$ & 0.005 & -0.014 & 0.032 & -0.005 & 0.061 \\
\hline
\end{tabular}

Notes: The dependent variable is disapproval of acquaintances engaging in fare dodging, coded 1-4 such that a higher number indicates stronger disapproval. The variable Risk preferences is coded such that higher values represent a higher risk tolerance. The variable Time preferences is coded such that higher values represent greater patience. For each personality trait, higher values represent a stronger intensity of that trait. A higher score on self-control indicates lower self-control. Robust standard errors in brackets, ${ }^{* * *} p<0.01, * * p<0.05, * p<0.1$. 
Table 2: The relationship between drunk driving and economic preferences, personality traits, self-control (ordered logit estimates)

\begin{tabular}{|c|c|c|c|c|c|}
\hline Explanatory variables & $(1)$ & $(2)$ & (3) & (4) & (5) \\
\hline \multirow[t]{2}{*}{ Age } & $1.442 * *$ & $1.349^{*}$ & $1.439 * *$ & $1.192 * *$ & $1.454^{* *}$ \\
\hline & {$[0.588]$} & [0.691] & [0.653] & {$[0.606]$} & {$[0.678]$} \\
\hline \multirow[t]{2}{*}{$\mathrm{Age}^{2}$} & $-0.030 * *$ & $-0.029 * *$ & $-0.031 * *$ & $-0.024 * *$ & $-0.031 * *$ \\
\hline & {$[0.012]$} & {$[0.014]$} & {$[0.013]$} & {$[0.012]$} & {$[0.014]$} \\
\hline \multirow[t]{2}{*}{ Male } & -0.411 & -0.051 & 0.139 & -0.600 & 0.131 \\
\hline & {$[0.441]$} & [0.451] & {$[0.465]$} & [0.439] & {$[0.475]$} \\
\hline \multirow[t]{2}{*}{ Risk preferences } & $-0.299 * * *$ & & $-0.229 * *$ & & $-0.243 * *$ \\
\hline & [0.088] & & [0.095] & & {$[0.101]$} \\
\hline \multirow[t]{2}{*}{ Time preferences } & -0.261 & & -0.387 & & -0.378 \\
\hline & [0.219] & & [0.248] & & [0.247] \\
\hline \multirow[t]{2}{*}{ Extraversion } & & -0.365 & -0.27 & & -0.275 \\
\hline & & {$[0.232]$} & [0.233] & & {$[0.236]$} \\
\hline \multirow[t]{2}{*}{ Agreeableness } & & 0.189 & 0.122 & & 0.131 \\
\hline & & {$[0.207]$} & {$[0.205]$} & & {$[0.215]$} \\
\hline \multirow[t]{2}{*}{ Conscientiousness } & & $0.781^{* * *}$ & $0.746 * * *$ & & $0.765 * * *$ \\
\hline & & {$[0.234]$} & {$[0.243]$} & & {$[0.258]$} \\
\hline \multirow[t]{2}{*}{ Neuroticism } & & $0.382 * *$ & 0.316 & & 0.302 \\
\hline & & [0.189] & [0.198] & & [0.203] \\
\hline \multirow[t]{2}{*}{ Openess } & & 0.108 & 0.204 & & 0.205 \\
\hline & & [0.232] & {$[0.232]$} & & {$[0.232]$} \\
\hline \multirow[t]{2}{*}{ Locus of Control } & & 0.043 & 0.075 & & 0.095 \\
\hline & & [0.222] & {$[0.250]$} & & {$[0.271]$} \\
\hline \multirow[t]{2}{*}{ Self-control } & & & & -0.033 & 0.008 \\
\hline & & & & {$[0.026]$} & {$[0.037]$} \\
\hline $\mathrm{N}$ & 180 & 180 & 180 & 180 & 180 \\
\hline Pseudo $\mathrm{R}^{2}$ & 0.076 & 0.119 & 0.148 & 0.038 & 0.148 \\
\hline Adjusted Pseudo R & -0.029 & 0.014 & 0.043 & -0.067 & 0.043 \\
\hline
\end{tabular}

Notes: The dependent variable is disapproval of acquaintances engaging in drunk driving, coded 1-4 such that a higher number indicates stronger disapproval. The variable Risk preferences is coded such that higher values represent a higher risk tolerance. The variable Time preferences is coded such that higher values represent greater patience. For each personality trait, higher values represent a stronger intensity of that trait. A higher score on self-control indicates lower self-control. Robust standard errors in brackets, ${ }^{* * *} p<0.01,{ }^{* *} p<0.05,{ }^{*} p<0.1$. 
Table 3: The relationship between tax evasion and economic preferences, personality traits, self-control (ordered logit estimates)

\begin{tabular}{|c|c|c|c|c|c|}
\hline Explanatory variables & (1) & $(2)$ & (3) & (4) & (5) \\
\hline \multirow[t]{2}{*}{ Age } & -0.847 & -0.924 & -0.93 & -1.014 & -1.026 \\
\hline & [0.856] & [0.685] & {$[0.720]$} & [0.858] & [0.697] \\
\hline \multirow[t]{2}{*}{ Age $^{2}$} & 0.018 & 0.019 & 0.019 & 0.022 & 0.020 \\
\hline & {$[0.018]$} & [0.014] & [0.015] & {$[0.018]$} & {$[0.014]$} \\
\hline \multirow[t]{2}{*}{ Male } & -0.09 & 0.466 & 0.565 & -0.049 & 0.586 \\
\hline & [0.337] & [0.382] & [0.396] & [0.340] & [0.403] \\
\hline \multirow[t]{2}{*}{ Risk preferences } & -0.105 & & -0.096 & & 0.004 \\
\hline & [0.081] & & [0.090] & & [0.101] \\
\hline \multirow[t]{2}{*}{ Time preferences } & -0.07 & & -0.226 & & -0.286 \\
\hline & [0.255] & & [0.285] & & [0.285] \\
\hline \multirow[t]{2}{*}{ Extraversion } & & -0.085 & -0.048 & & -0.009 \\
\hline & & {$[0.175]$} & {$[0.181]$} & & [0.188] \\
\hline \multirow[t]{2}{*}{ Agreeableness } & & $0.375^{* *}$ & $0.351 * *$ & & 0.294 \\
\hline & & {$[0.172]$} & [0.173] & & [0.182] \\
\hline \multirow[t]{2}{*}{ Conscientiousness } & & $0.460 * * *$ & $0.450 * * *$ & & $0.324^{*}$ \\
\hline & & [0.167] & [0.168] & & {$[0.180]$} \\
\hline \multirow[t]{2}{*}{ Neuroticism } & & 0.324 & 0.303 & & $0.415^{* *}$ \\
\hline & & {$[0.200]$} & [0.198] & & {$[0.210]$} \\
\hline \multirow[t]{2}{*}{ Openess } & & $0.320^{*}$ & $0.367^{*}$ & & $0.373 * *$ \\
\hline & & [0.172] & [0.189] & & {$[0.181]$} \\
\hline \multirow[t]{2}{*}{ Locus of Control } & & 0.23 & 0.25 & & 0.115 \\
\hline & & [0.171] & [0.178] & & [0.191] \\
\hline \multirow[t]{2}{*}{ Self-control } & & & & $-0.057 * * *$ & $-0.055 * *$ \\
\hline & & & & {$[0.017]$} & [0.023] \\
\hline $\mathrm{N}$ & 180 & 180 & 180 & 180 & 180 \\
\hline Pseudo $\mathrm{R}^{2}$ & 0.012 & 0.070 & 0.076 & 0.043 & 0.095 \\
\hline Adjusted Pseudo $\mathrm{R}^{2}$ & -0.071 & -0.013 & -0.007 & -0.040 & 0.011 \\
\hline
\end{tabular}

Notes: The dependent variable is disapproval of acquaintances engaging in tax evasion, coded 1-4 such that a higher number indicates stronger disapproval. The variable Risk preferences is coded such that higher values represent a higher risk tolerance. The variable Time preferences is coded such that higher values represent greater patience. For each personality trait, higher values represent a stronger intensity of that trait. A higher score on self-control indicates lower self-control. Robust standard errors in brackets, ${ }^{* * *} p<0.01,{ }^{* *} p<0.05, * p<0.1$. 
Table 4: The relationship between stealing and economic preferences, personality traits, self-control (OLS estimates)

\begin{tabular}{|c|c|c|c|c|c|}
\hline Explanatory variables & $(1)$ & $(2)$ & (3) & $(4)$ & $(5)$ \\
\hline \multirow[t]{2}{*}{ Age } & $-5.677 * * *$ & $-5.267 * * *$ & $-5.261 * * *$ & $-5.494 * * *$ & $-5.131 * *$ \\
\hline & [2.054] & [1.993] & [2.001] & {$[2.045]$} & [2.090] \\
\hline \multirow[t]{2}{*}{$\mathrm{Age}^{2}$} & $0.125^{* * *}$ & $0.115^{* * *}$ & $0.115^{* * *}$ & $0.121 * * *$ & $0.113 * * *$ \\
\hline & [0.043] & {$[0.041]$} & [0.041] & {$[0.042]$} & [0.043] \\
\hline \multirow[t]{2}{*}{ Male } & 1.437 & 1.809 & 1.667 & 1.189 & 1.633 \\
\hline & [1.209] & [1.287] & [1.307] & [1.183] & [1.282] \\
\hline \multirow[t]{2}{*}{ Risk preferences } & 0.124 & & 0.144 & & -0.056 \\
\hline & [0.257] & & {$[0.286]$} & & [0.304] \\
\hline \multirow[t]{2}{*}{ Time preferences } & 0.167 & & 0.374 & & 0.506 \\
\hline & {$[0.768]$} & & {$[0.803]$} & & [0.805] \\
\hline \multirow[t]{2}{*}{ Extraversion } & & $1.402 * *$ & $1.340 * *$ & & $1.253^{* *}$ \\
\hline & & {$[0.563]$} & {$[0.584]$} & & {$[0.584]$} \\
\hline \multirow[t]{2}{*}{ Agreeableness } & & -0.265 & -0.211 & & -0.069 \\
\hline & & [0.540] & [0.534] & & {$[0.535]$} \\
\hline \multirow[t]{2}{*}{ Conscientiousness } & & 0.314 & 0.342 & & 0.607 \\
\hline & & [0.632] & {$[0.660]$} & & [0.696] \\
\hline \multirow[t]{2}{*}{ Neuroticism } & & 0.553 & 0.599 & & 0.402 \\
\hline & & [0.562] & [0.578] & & {$[0.600]$} \\
\hline \multirow[t]{2}{*}{ Openess } & & -0.649 & -0.712 & & -0.697 \\
\hline & & {$[0.563]$} & [0.584] & & {$[0.575]$} \\
\hline \multirow[t]{2}{*}{ Locus of Control } & & -0.952 & -0.986 & & -0.703 \\
\hline & & [0.604] & [0.620] & & [0.662] \\
\hline \multirow[t]{2}{*}{ Self-control } & & & & $0.107^{*}$ & 0.105 \\
\hline & & & & {$[0.060]$} & [0.077] \\
\hline \multirow[t]{2}{*}{ Constant } & $74.416 * * *$ & $71.052 * * *$ & $69.393 * * *$ & $73.126 * * *$ & $68.258 * * *$ \\
\hline & {$[24.560]$} & [24.084] & [24.173] & {$[24.508]$} & [25.095] \\
\hline $\mathrm{N}$ & 180 & 180 & 180 & 180 & 180 \\
\hline $\mathrm{R}^{2}$ & 0.050 & 0.098 & 0.100 & 0.070 & 0.111 \\
\hline Adjusted $\mathrm{R}^{2}$ & 0.023 & 0.050 & 0.041 & 0.048 & 0.047 \\
\hline
\end{tabular}

Notes: The dependent variable is the number of points (out of 20) stolen from another passive participant. The variable Risk preferences is coded such that higher values represent a higher risk tolerance. The variable Time preferences is coded such that higher values represent greater patience. For each personality trait, higher values represent a stronger intensity of that trait. A higher score on self-control indicates lower self-control. Robust standard errors in brackets, $* * * p<0.01, * * p<0.05, * p<0.1$. 